\title{
GENUINE SAVINGS FOR MALAYSIA: WHAT DOES IT TELL?
}

\author{
JAMAL OTHMAN \\ ROBY FALATEHAN \\ YAGHOOB JAFARI \\ Faculty of Economics and Management \\ Universiti Kebangsaan Malaysia
}

\begin{abstract}
s
Resource and environmental economists have argued that the conventional GDP is not an adequate indicator to reflect if an economy is growing sustainably, as it does not consider the changes in national capital and pollution impacts. The World Bank Genuine Savings indicator, though in the weak sustainability form, provides an alternative measure. This paper calculates the Genuine Savings for Malaysia from 1990-2008. While the results show that the Genuine Savings for Malaysia has been positive, its ratio to GDP declines markedly following the economic crisis of 1997/98. Comparisons with selected countries, especially South Korea and Indonesia are also made. Policy implications are deliberated at the end of the paper.
\end{abstract}

Keywords: Malaysian genuine savings, sustainability path, macroeconomic sustainability measure.

\section{Introduction}

For the past thirty years, Malaysia has pursued a rapid economic growth course viz attracting foreign investments and proactive industrialization processes. Thus far, according to the conventional GDP indicator, Malaysia to a large extent, has been able to sustain a positive economic growth trajectory. However, there are increasing concerns world-wide that the conventional GDP may not be adequate to reflect if an economy is growing sustainably, as it essentially does not capture the changes in national capital or assets and pollution impacts. Hence, an important and growing apprehension is whether Malaysia's economy is moving on the sustainable growth path.

Although the fallacy of the GDP indicator as a true measure of economic performance in aggregate has long been noted, the need for alternative indicators became an increasingly important issue 
especially after the UN Conference on Environment and Development in 1992. Agenda 21 specially stressed very explicitly the need for the world at large to develop the capacity to assess the true progress of the economy.

Pearce, Markandya and Barbier (1989) pointed out that the operational definition of sustainable development in the weak sustainability paradigm is that the total stock of capital, including, man-made capital, human capital, natural capital and even social capital should be maintained as a necessary condition to maintain future well-being. This was based on his earlier work where he extended the Hartwick (1977) rule to devise the term Genuine Savings (GS). Essentially GS defines the sustainability conditions for non-renewable resource dependent economy on the ability to maintain a constant stream of consumption into the infinite future. This can be achieved via a savings and investment rule that ensures the aggregate stock of physical and natural capital remains constant over time.

In support of Pearce, Vincent (2001) strongly attributed the inability of many resource-rich economies to achieve long-term welfare improvements to the failure of the said countries to offset the depletion of natural resource stocks with sufficient investments in physical capital and human capital; consequently, their total wealth -the sum of physical, human, and natural capital declines.

The Genuine Savings (GS) (or sometimes known as Adjusted Net Savings) indicator broadly measures the aggregate net savings in a country that takes into account the depletion of natural resources and pollution. There have been three main approaches to calculate the GS, viz; (a) the approach developed by the United Nations Commission on Sustainable Development in 1995, (b) Correction of the System of National Account (SNA) via the System of Environmental-Economic Accounts (SEEA) developed by the United Nations Statistical Division (UNSD) in 1993, and (c) The World Bank's measure of the wealth of nations in 1997. Of the three, the third approach has been widely applied for many countries.

Operationally, the GS is defined as;

Genuine Saving = Gross Domestic Saving - Consumption of Fixed Capital +Education Expenditure - Natural Resource Depletion - Pollution Damages

A negative GS rate denotes that in aggregate the national capital is depleting faster than renewed. A positive GS is desirable, however, it 
still does not guarantee sustainability in the strict sense of the term, because the indicator is based on the weak sustainability paradigm. The weak sustainability principle assumes that natural capital can be perfectly substituted by man-made capital.

This study calculates the World Bank's measure of GS to appraise the economic growth trajectory of Malaysia from 1990 to 2008. Comparisons with selected economies, especially of South Korea and Indonesia are also made. Policy implications are deliberated at the end of the paper.

\section{Methods}

The World Bank published the first cross-country estimates of GS in 1997. It began to include them in the World Development Indicators series in 1999. The World Bank constructs these estimates by making appropriate adjustments to the Gross National Savings figures. The major adjustments are to subtract a depreciation allowance for manmade capital and depletion allowances for fossil fuels, minerals, and timber, and to add investment in human capital. Hamilton and Clemens (1999) and Bolt, Matete, and Clemens (2002) detailed out the theoretical constructs of GS as well as the practical methods as used by the World Bank to make these adjustments. The methods are similar across countries and generally rely on standard international data sources.

\section{Gross Domestic Savings}

The first step in calculating the GS is the estimation of gross domestic savings (GDS). Gross domestic savings, according to standard national accounting (SNA) are calculated as the difference between gross domestic product (GDP) and public and private consumption.

Information about GDS for Malaysia is published regularly by the Asian Development Bank. The data for GDS in this study was obtained from this source.

Trend of GDS for Malaysia is shown in Figure 1. It shows a steady growth of 8 per cent annually, from USD15,146 million in 1990 to USD94,029 million in 2008. A sharp decline was noted in 1997/98 due to the Asian financial crisis. 
IJMS 19 (1), 151-174 (2012)

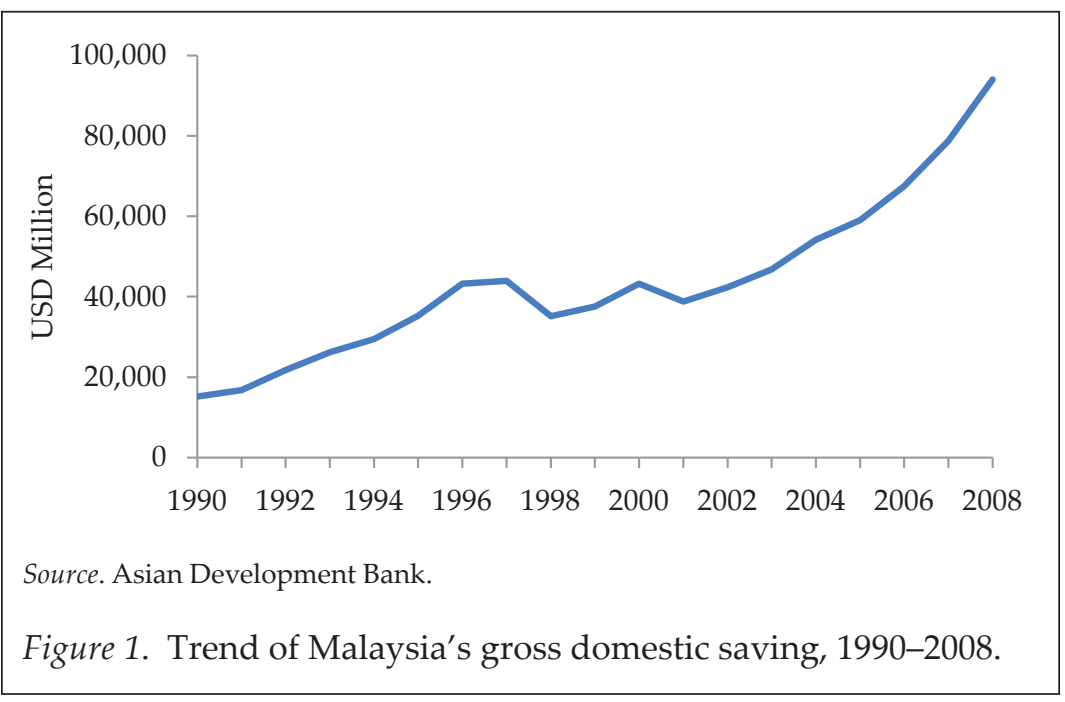

\section{Consumption of Fixed Capital}

Consumption of fixed capital represents the replacement value of the capital used in the process of production. Data on the consumption of fixed capital in Malaysia was taken from the World Bank, for various years.

As shown in Figure 2, the consumption of fixed capital in Malaysia increased markedly at 7 per cent annually from USD4,816 million in 1990 to USD25,494 million in 2008. There was a sharp fall in 1998, which was attributed to the Asian economic crisis at the time.

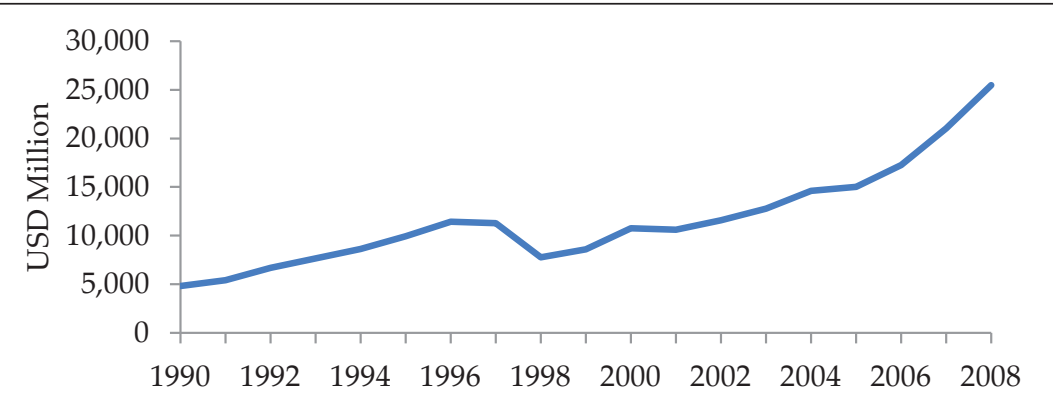

Source. The World Bank.

Figure 2. Trend of Malaysia's consumption of fixed capital, 1990-2008. 


\section{Education Expenditure}

Education expenditure data contains operating expenditures, wages and salaries but excludes capital investments in building and equipment. In the GS model, current expenditures on education are added to net domestic savings to proxy the value of investments in human capital. Note that in the SNA, these expenditures are treated as consumption. Data for Malaysia was taken from the Economic Report of the Ministry of Finance Malaysia for various years.

Figure 3 indicates that the trend of education expenditure in Malaysia was increasing annually at 7-8 per cent from 1990 to 2008. Like the earlier variables, education expenditure during the 1997/98 economic crisis dipped markedly.

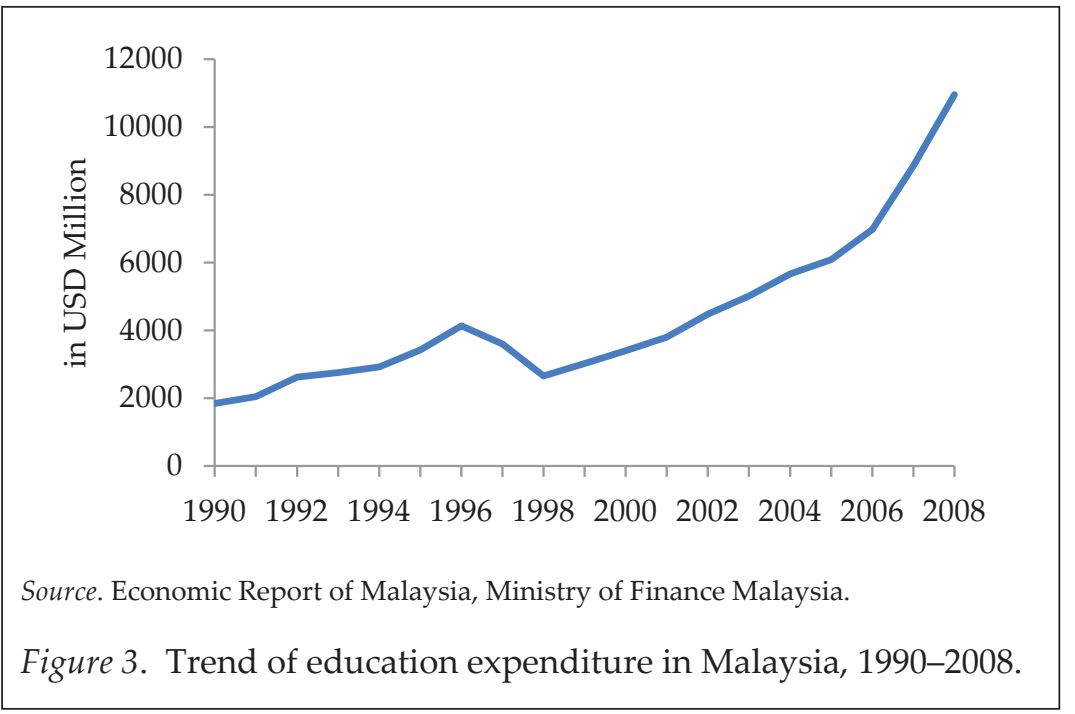

\section{Depletion of Natural Resources}

Depletion of natural resources is measured as the total rents on resources extracted and harvested. There are two categories of natural resources - non-renewable and renewable resources. Non-renewable resources are divided into mineral resources and energy resources. In this study, mineral resources include bauxite, tin, gold and iron ore while energy resources are petroleum, gas and coal. Depletion costs are valued based on economic rents. The World Bank estimated economic rents as the difference between the value of production at world prices and the total production costs. 
This study calculates renewable resource based on the value of timber only. Other environmental services provided by forests such as biodiversity, carbon storage, watershed protection and other nontimber benefits are excluded. The study also omits other natural assets such as fisheries resources and the economic costs of soil degradation. The World Bank estimates timber rents by multiplying the difference between production and increments with the product of average price and rental price. In this study, however, forest/timber depletion is estimated using the Net Price Method, where timber rents are computed as the difference between the rental value (price less average logging cost) of log harvests and the corresponding value of natural growth of natural and plantation forests.

\section{Pollution Damages}

Pollution damage is calculated only for $\mathrm{CO}_{2}$, using a global estimate of marginal social cost of US\$20 per metric ton of carbon emitted. Carbon dioxide emissions, largely by-products of energy production and use, account for the largest share of greenhouse gases globally.

\section{Sources of Data}

The data used in calculating the GS are drawn from various domestic and international sources. Gross Domestic Savings data came from the Asian Development Bank, Consumption of Fixed Capital from the World Bank and Education Expenditure from the Economic Report of the Ministry of Finance, Malaysia for 2000-2008, and Shahril Marzuki (2005) for 1990-1999. Data for the production of minerals and energy are sourced from the United States Geological Survey, timber production from the Statistic Year Book Malaysia while natural resources and $\mathrm{CO}_{2}$ production came from the World Bank.

The IMF provides data for prices for energy and minerals (except gold) while timber prices for Malaysia are taken from the Department of Forestry, Peninsular Malaysia. Data for $\mathrm{CO}_{2}$ prices are obtained from the United Nations (ESCAP Division).

For the cost of production, data for bauxite came from the Saudi Network, tin from PT Timah, Indonesia, iron ore from Ferret, Australia, while gas and petroleum from British Petroleum. Meanwhile, data for the cost of gas production are sourced from Bank Indonesia and lastly, the cost of timber production in Malaysia for the 2005 base year is based on the study by Awang Noor, et al. (2007). 
Tables A2-A6 detail out the sources of data for each element in the calculation of Genuine Savings for Malaysia.

\section{Genuine Savings for Malaysia}

This section presents the results of the GS estimation for Malaysia and compares with that of its GDP. The calculated GS will show if Malaysia has been saving enough in terms of its overall capital to sustain its socio-economic development and related achievements. Note that negative GS rates or a marked downtrend are a serious 'flag' denoting unsustainability.

Results show that Malaysia's GS has been positive during 1990-2008. This indicates quite well that Malaysia's economy has been operating on the sustainability track. Figure 4 seems to suggest that the growth path of the Malaysian GS is lower than its GDP. However, its annual growth rate is calculated to be higher (7.7 per cent) relative to GDP (7 per cent). However, this deviation can be strongly attributed to the structural change in the Malaysian GDP trajectory starting in 1997/98, which was the outset of the East Asian economic crisis.

Further investigation reveals that following the economic crisis of 1997/98, Malaysia's overall GDP growth contracted by 2.2 per cent, while GS growth declined more pronouncedly by 9 per cent. While the positive GS achievement is enlightening, the larger decline of GS growth in the post-crisis period causes serious concerns on Malaysia's future capital accumulation capacity. For the entire 1990-2008 period, a positive association is observed between GS and GDP where a simple regression indicates a one per cent change in GDP is associated with a one per cent change in GS (unitary elasticity).

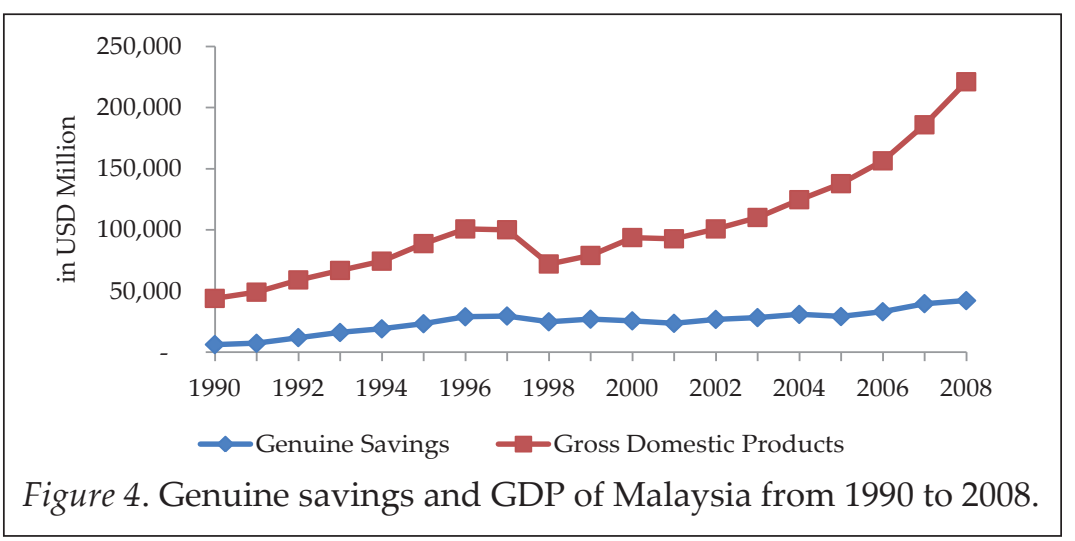


Figure 5 shows the plot of GS to GDP ratio. It shows a definite pattern where the ratio was increasing in the period prior to 1997/98 but declined thereafter. This signifies to some extent the declining capacity of the Malaysian economy to sustain the levels of overall national capital for future productive activities.

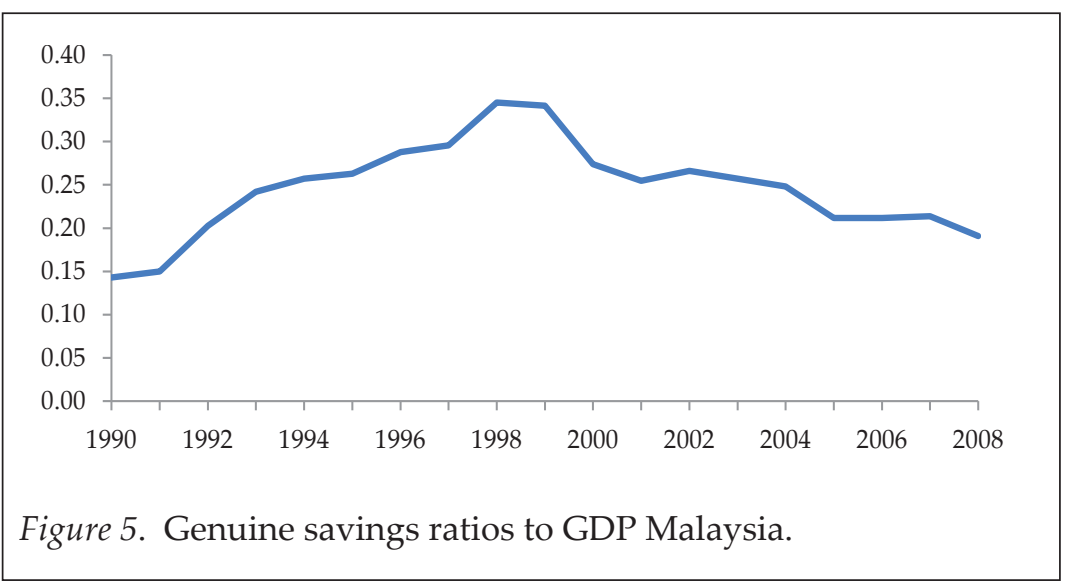

Figure 6 tells if there are compelling reasons for immediate concerns to change the current macroeconomic and environmental policies. The dots in the top right quadrant indicate that the Malaysian economy is experiencing both positive GDP and GS growth, while the dots in the top left quadrant show negative GDP growth yet positive GS achievement. The findings reflect that Malaysia was still capable of investing in the present generation for future needs despite the economic crisis.

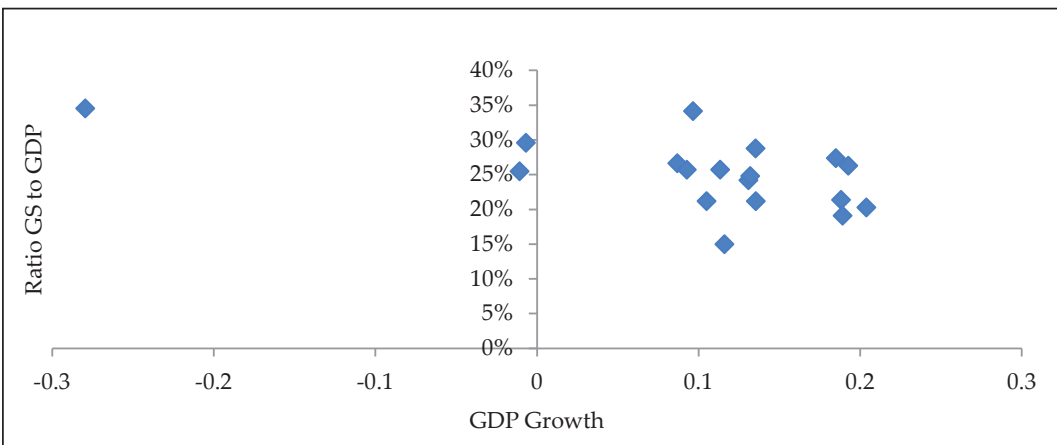

Figure 6. Genuine savings rates against economic growth. 


\section{Elements of Genuine Savings}

Figure 7 and Table 1 list the elements of GS. The highest ranking ratio is GDS, where from 1990-2008 it averages around 176 per cent. This is followed by consumption of fixed capital at 48 per cent and cost of energy depletion, at around 35 per cent. Education expenditure is fourth in ranking at 18 per cent, followed by forest depletion ( 7 per cent), emission of $\mathrm{CO}_{2}$ (3 per cent), and lastly, cost of mineral depletion at 0.19 per cent.

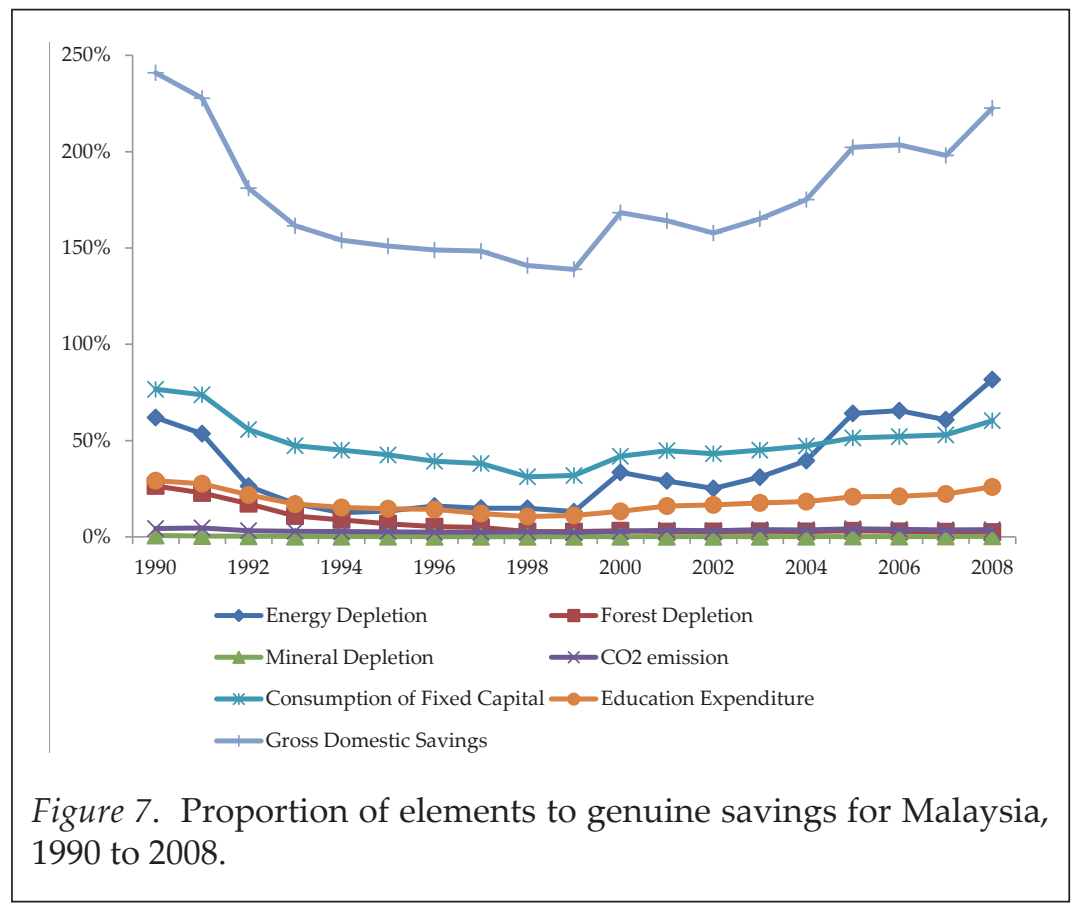

Table 1

Average of Genuine Savings Elements Ratio for Malaysia, from 1990 to 2008

\begin{tabular}{|c|c|c|c|c|c|c|c|}
\hline & Mineral & Energy & $\mathrm{CO} 2$ & Forest & Capital & Education & GDS \\
\hline Average & $0.19 \%$ & $35.52 \%$ & $3.31 \%$ & $7.08 \%$ & $48.44 \%$ & $18.20 \%$ & $176.35 \%$ \\
\hline
\end{tabular}

The trend for the top four elements is the same where it declines towards 1997/98 (before the Asian crisis), but increases thereafter. Forest depletion declines steadily throughout the study period. Meanwhile 
the trends for $\mathrm{CO}_{2}$ emissions and the cost of mineral depletion have been rather flat. For natural resources, energy depletion represents the highest cost, where its trend falls from 1990-1998, then rises until 2008. Mineral depletion constitutes the lowest cost at less than 0.5 per cent of GS throughout the study period.

\section{Positive GS Elements}

Positive GS elements refer to GDS and education expenditure. These two trends demonstrate similar patterns (Figures 8 and 9). Both GDS and education expenditure increase along with increases in GDP. However, the GDP trend seems to indicate a slightly larger rate of growth relative to GDS especially after 1998.

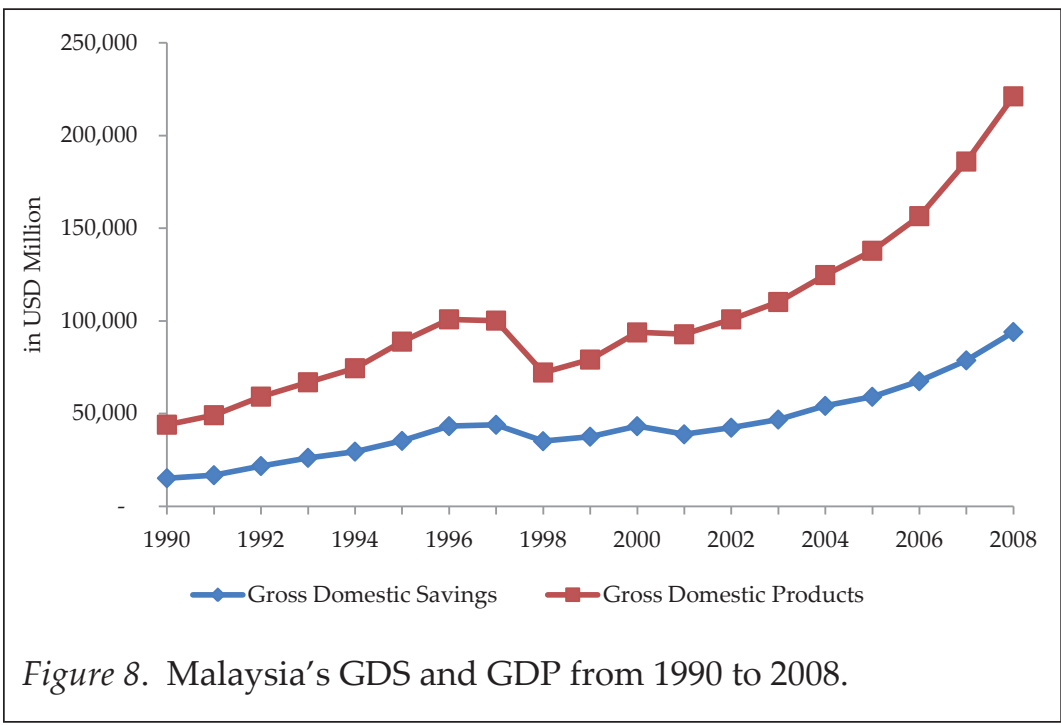

With regards to changes in Malaysia's education expenditure, the ratio of education expenditure to GDP seems to fall from 1990-97 but rises thereafter (Figure 9). Since education expenditure is a positive element in GS, there is need to ensure that it contributes meaningfully to human capital formation. Otherwise, the positive trend may result in biased policy implication or a false sense of comfort.

There are two negative elements within the GS framework. These are pollution costs $\left(\mathrm{CO}_{2}\right.$ emission) and natural resource depletion. For the latter, it includes depletion in renewable and non-renewable resources. 


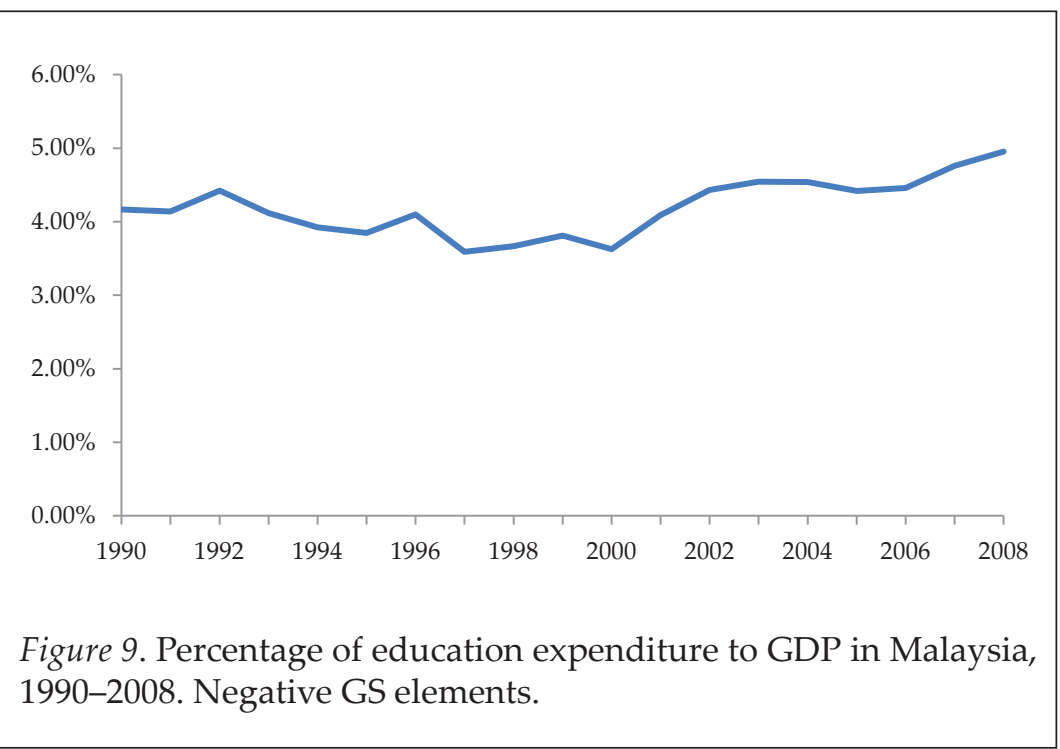

According to Figure 10, of the four negative elements of the GS, energy depletion costs are most prominent. The percentage of energy depletion costs to GDP declines sharply from 1990 to 1994; thereafter increases markedly from 1994-2008.

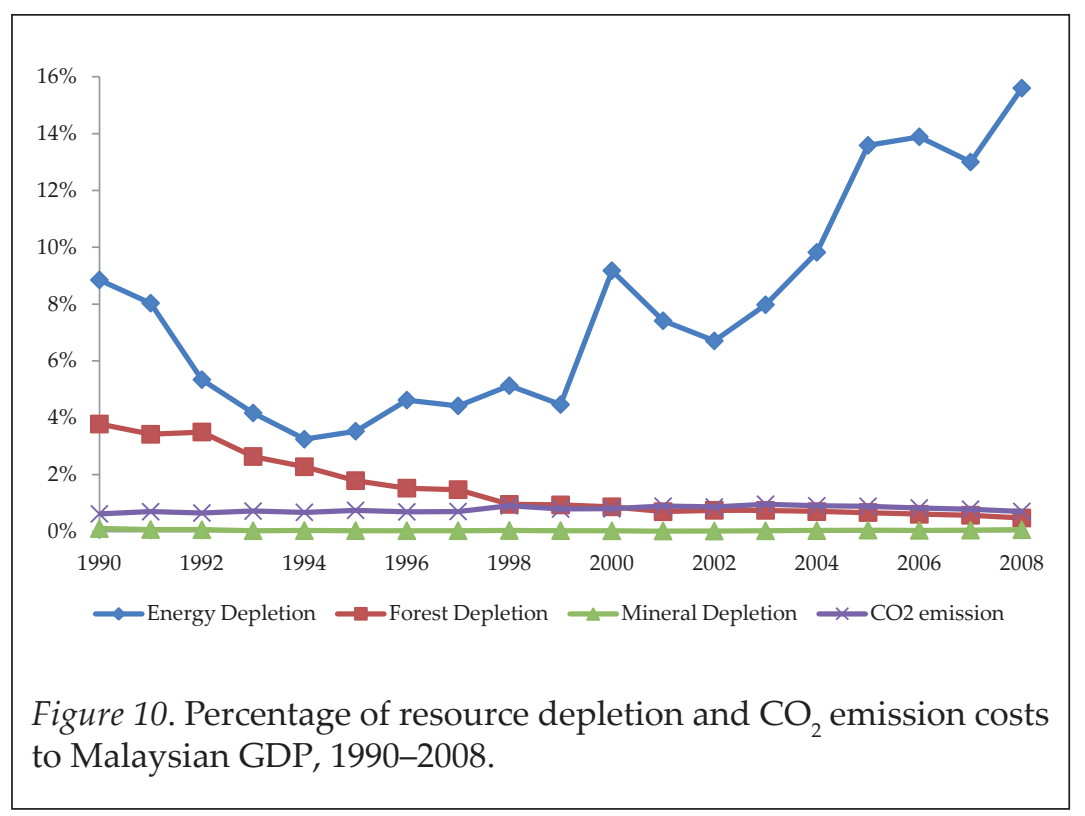


For the forest sector, timber depletion rate continues to fall over the years but at a lower rate from 1997-2008. For $\mathrm{CO}_{2}$ emission, the depletion rate centers around 1 per cent of GDP, while for mineral depletion, it is mainly under 1 per cent of GDP throughout the years.

This study also calculates the cost of forest depletion using the El Serafy Method (El Serafy, 1989) and Change in Asset Value Method (CAVM). The merits and weaknesses of each of these methods have been well established in the literature. Results from the two methods are compared with that of the Net Price Method and the World Bank approach. Figure 11 shows each method yields different results but a consistent pattern from 1990 to 2008 . The highest depletion rates are derived from the CAVM, followed by the El Serafy, this study (Net Price Method), and the World Bank approach. Note the proportion of forest depletion cost to GDP calculated using the Net Price Method is higher than the World Bank estimates. The difference is mainly attributed to differences in approaches, price and cost parameters used in calculating timber rents.

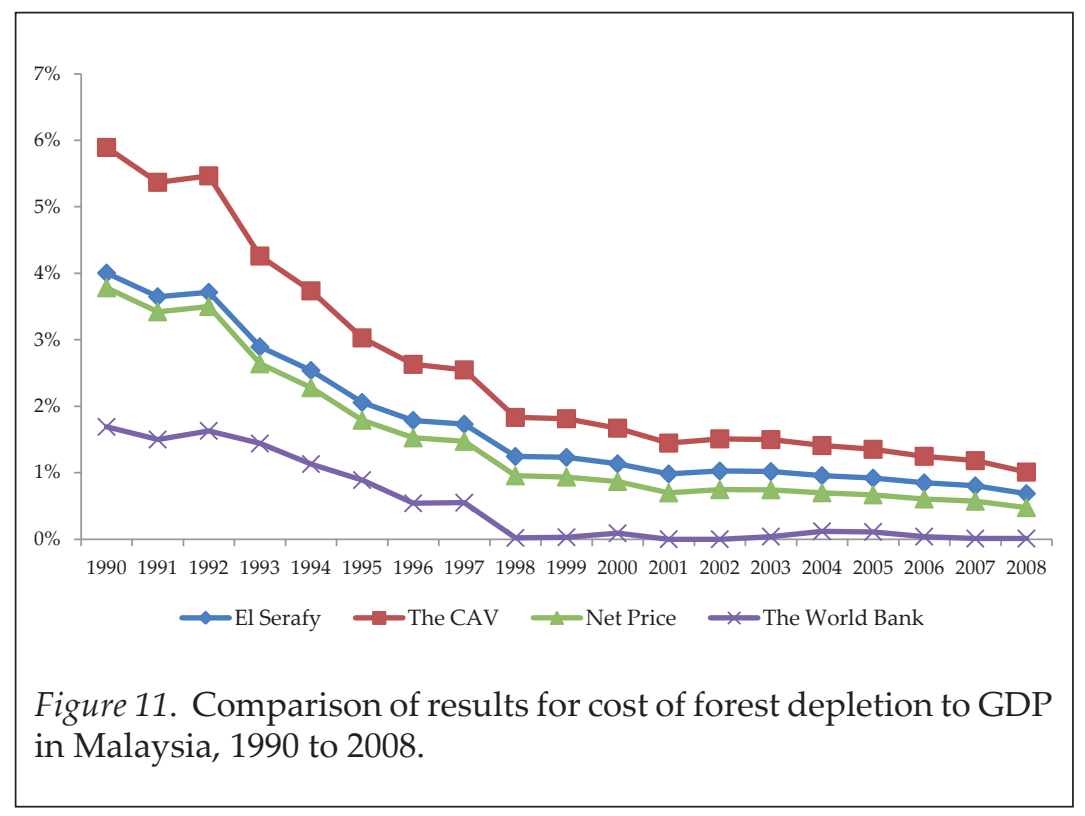

\section{Adjustments to Genuine Savings}

Figure 12 summarizes the relative adjustments to GS for Malaysia, for 1990 and 2008. 


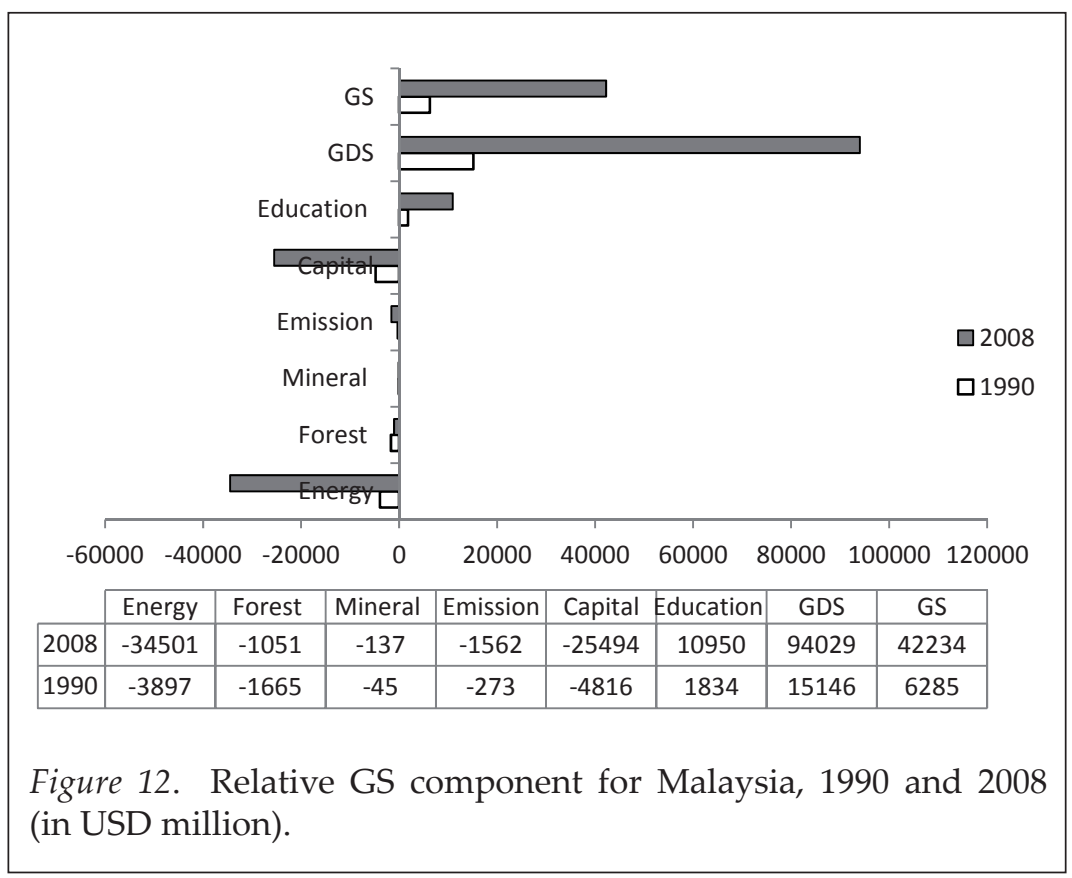

Both GDS and education expenditure have substantial positive impacts and their growth rates are fairly high during the study period. On the other hand, energy and fixed capital depletion pose strong downward impacts on GS.

\section{Comparison with the World Banks Estimates}

The World Bank produces GS estimates for many countries in the world, including Malaysia. The World Bank uses a longer data series, from 1960 to 2009. Comparison of our GS calculation with that of the World Bank will be important to ascertain if the two approaches produce consistent results.

Figure 13 compares the GS proportion to GDP for Malaysia between our analysis and the World Bank from 1990-2007. While the trend of GS is somewhat similar, the value of GS based on our calculation is consistently higher than the World Bank estimates. 
IJMS 19 (1), 151-174 (2012)

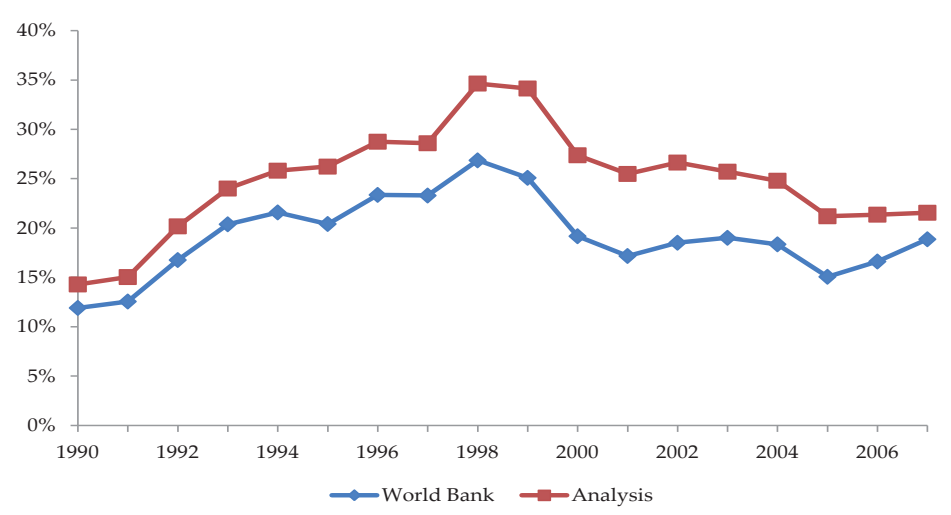

Figure 13. Comparison of calculated GS to GDP ratio with the World Bank estimates, 1990-2007.

\section{Experiences of Other Countries}

This section overviews the experiences of GS in other countries, namely South Korea and Indonesia based on World Bank data on GS.

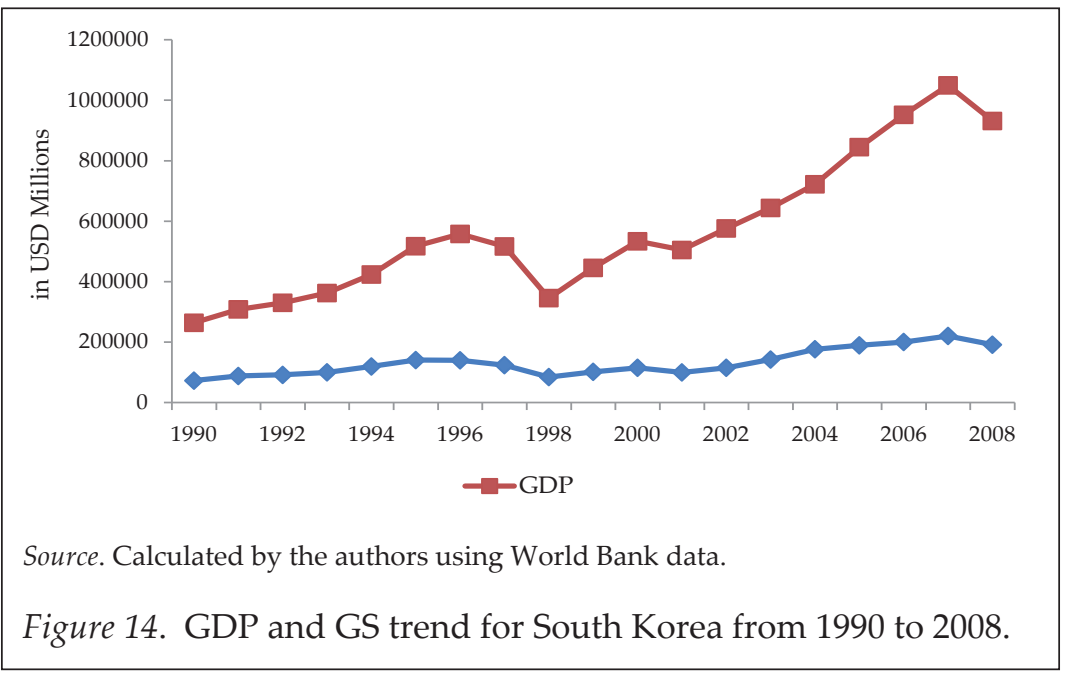

\section{South Korea}

South Korea's economic growth has been very rapid and robust, at 8.34 per cent annually from 1990 to 2008 . Expectedly, her GS increases 
along with GDP (Figure 14). In contrast to Malaysia, the ratio of South Korea's GS to GDP from 1990 - 2001 has been declining but depicts a general uptrend thereafter (Figure 15). Overall, like Malaysia, the GS values reflect South Korea's economy is moving on a sustainable growth path.

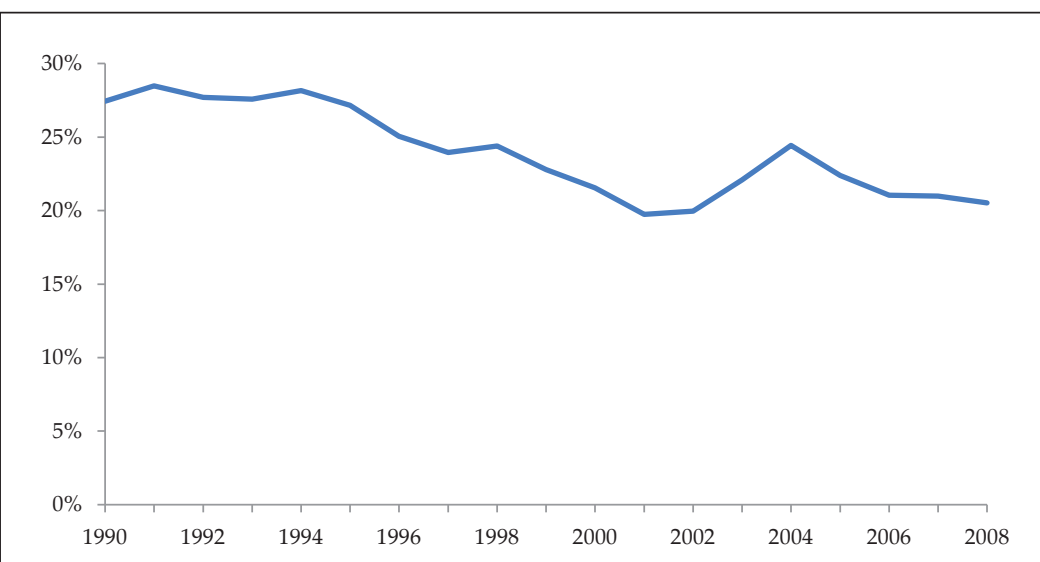

Figure 15. Ratio of genuine savings to GDP for South Korea from 1990 to 2008.

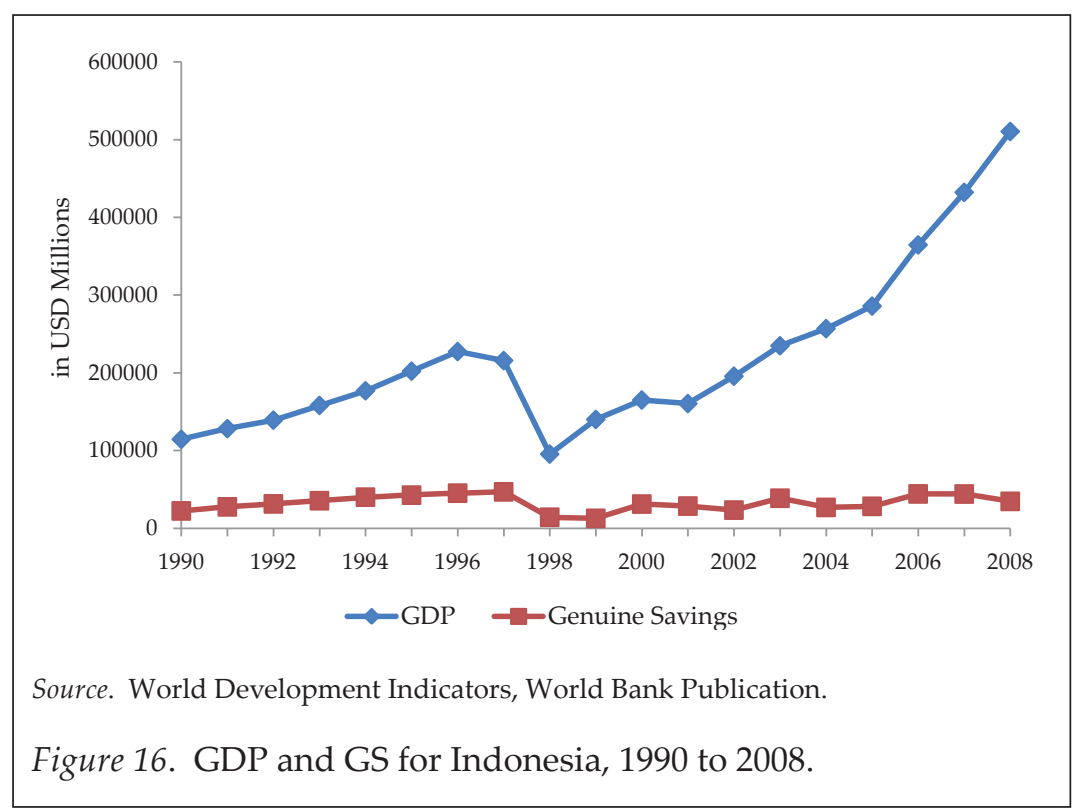


IJMS 19 (1), 151-174 (2012)

\section{Indonesia}

Indonesia constitutes one of the biggest natural resource-based economies in the world. Hence, it will be important for policy makers in the country to monitor its GS performance continuosly. In Figure 16 , Indonesia's GDP is shown to rise very rapidly at some 11 per cent annually. However, its GS while positive is rather flat (Figure 17). The divergence between GDP and GS growth for Indonesia seems to be the largest relative to Malaysia and South Korea. In fact the trend of Indonesia's GS to GDP ratio decreases very pronouncedly from 19.5 per cent in 1990 to 6.7 per cent in 2008.

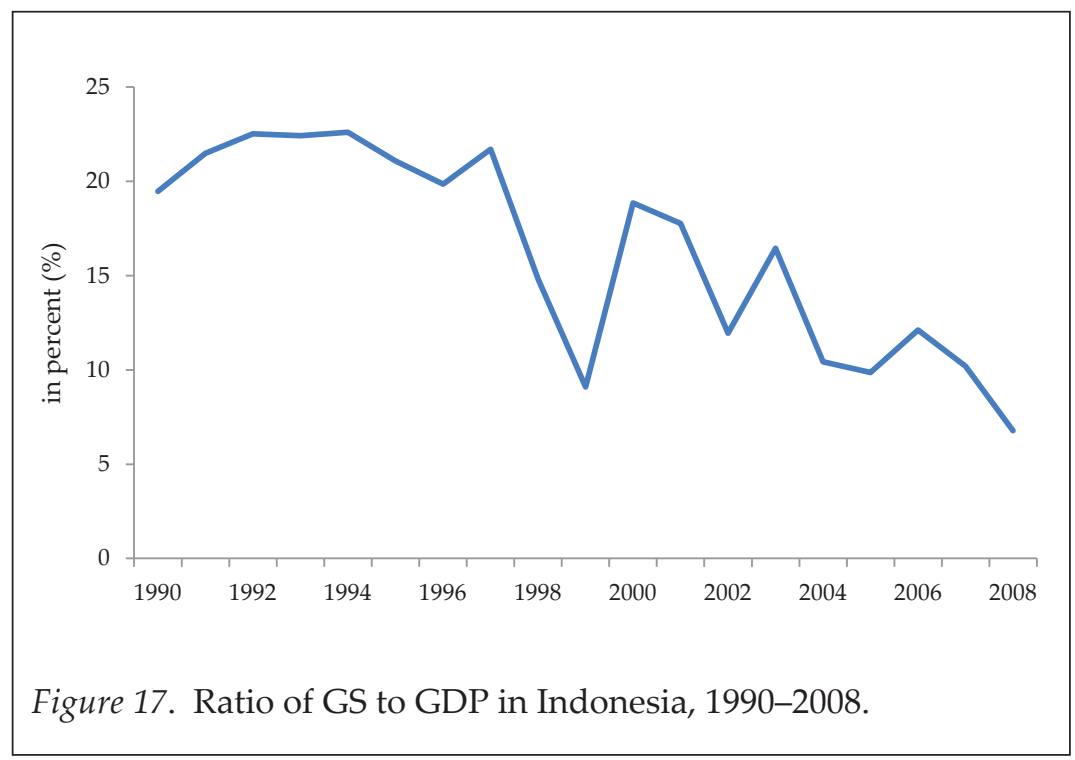

Figure 18 shows the calculated negative GS elements for energy, minerals, $\mathrm{CO}_{2}$ emission damages and consumption of fixed capital for Indonesia. Note in the World Bank calculation, net forest depletion has not been estimated for Indonesia.

For Indonesia, the largest two GS negative elements are consumption of fixed capital and energy depletion. Both trends are rising and resemble that of Malaysia. Other negative elements are somewhat stable and below 1 per cent to GDP throughout. 


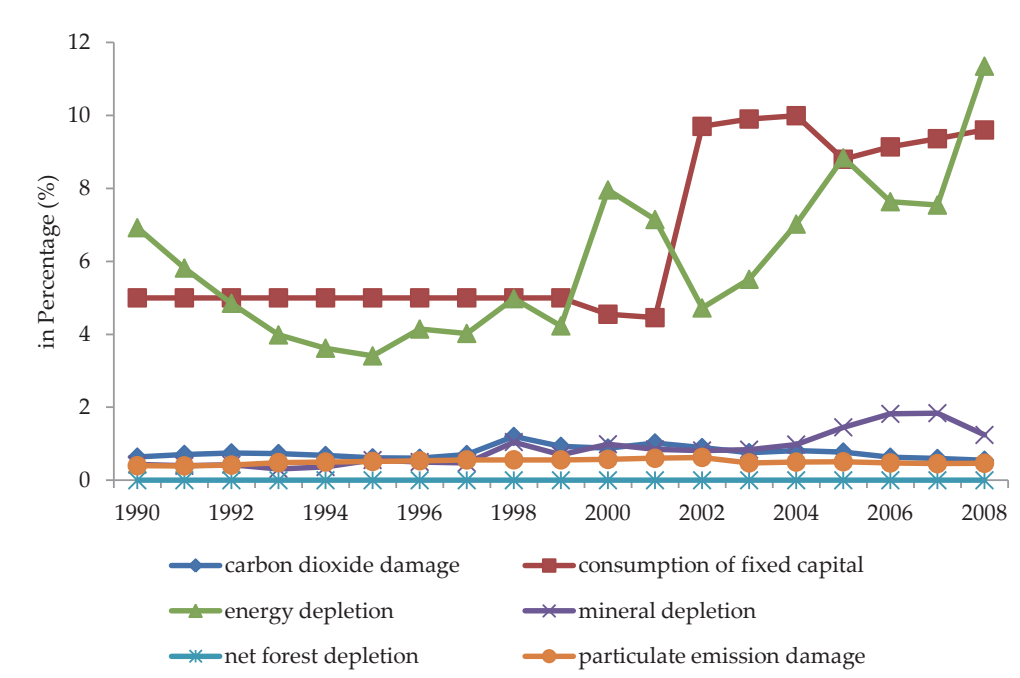

Source. Calculated from World Development Indicators, World Bank Publication.

Figure 18. Proportion of negative GS elements to GDP for Indonesia, 1990-2008.

\section{Concluding Remarks and Policy Implications}

The GS indicator, unlike the conventional GDP, provides information if an economy is moving on the path of sustainability, albeit in the weak sustainability sense. This study calculated the GS for Malaysia from 1990 - 2008. The study produces higher GS estimates than that of the World Bank, however, the trend pattern is similar. Results indicate Malaysia's economy is operating on the path of sustainability which suggests that her overall productive capacity is not reduced over time. However, the capacity of the Malaysian economy to sustain its wealth accumulation on a per GDP basis seems to decline markedly following the Asian financial crisis of 1997/98. Depletion in natural resources has also been high and increasing, especially for energy resource. Appropriate strategies need to be devised to increase further investment in reproducible and meaningful human capital to offset the depletion of natural resources as well as physical capital. It is also imperative to ensure that the education sector is truly capable to produce meaningful future human and social capital as they feature very prominently as a positive element in the GS calculation. 
The GS for South Korea and Indonesia has also been positive. However, for Indonesia, the ratio of GS to GDP in the post-Asian financial crisis period declined more pronouncedly relative to Malaysia and South Korea. Overall findings suggest Malaysia's GS performs better than Indonesia and comparable to that of South Korea.

The GS calculation is based on capital approach. This implies that as assets are increasingly depleted, the shadow price of the asset will be magnified. Therefore the value for natural capital depreciation becomes increasingly large. It also ignores the measurement of most non-marketed goods and services including critical environmental resources. Methods are available (for instance the Contingent Valuation approach) to measure the changes in the stocks of critical natural capital, however, this poses a number of practical and conceptual difficulties at least in the short-run. It is also important to be aware that the GS approach relies on the weak measure of sustainability, where it implicitly assumes that all assets can substitute each other in generating economic growth.

In view of the importance of the GS indicator to reflect the macroeconomic sustainability path of an economy, it is recommended that the Malaysian national statistical department look into ways to develop a system where pertinent GS data inputs can be obtained on a routine basis from the respective line agencies. This will enable the calculation of the GS in a fast and efficient manner, yet yielding reliable estimates.

For future research, it will be a strategic initiative for the Malaysian GS to be calculated and appraised for the various states or regions, especially the relatively resource-richer states such as Terengganu, Kelantan, Sabah and Sarawak. It will also be imperative for future research to consider more comprehensive inclusion of the GS elements and to enhance the evaluation methodology for more vigorous appraisals of the macro sustainability path of the Malaysian economy.

\section{References}

Alisjahbana, A. S., Arief, A. Y., \& Budiono. (2003). Measuring sustainable development in Indonesia: Genuine Savings and changes in wealth per capita. EADN Working Paper No. 20 (2003) Final report of an EADN research grant project. 
Bolt, K., Matete, M., \& Clemens, M. (2002). Manual for calculating adjusted net savings. Environment Department, World Bank.

El Serafy, S. (1989). The proper calculation of income from depleting natural resources. In Y. J. Ahmad, S. El Serafy \& E. Lutz, (Eds.), Environmental accounting for sustainable development. Washington, D.C.: The World Bank.

Glyn, E., \& Alex, W. (1999). The world bank's genuine savings indicator: A useful measure of sustainability? October 1999. Bretton Woods Project.

Kirk, H., \& Michael, A. C. (1999). Genuine savings rates in developing countries. World Bank Economic Review, 13(2), 333-356.

Lin, G. T. R., \& Chris, H. (2004). Genuine savings measurement and its application to the United Kingdom and Taiwan. The Developing Economies, XLII-1 (March2004), 3-41

OECD. (2001). Sustainable development: Critical issues. Organization for Economic Co-operation and Development, Paris.

Pearce, D. W., Markandya A., \& Barbier, E. (1989). Blueprint for a green economy. London: Earthscan Publications.

Pearce, D. W., \& Atkinson, G. (1993). Capital theory and the measurement of sustainable development: An indicator of weak sustainability. Ecological Economics, 8(1993), 103-108.

Shahril Marzuki, Chairil (2005). Mengurus dan membiayai pendidikan di Malaysia. Selangor: PTS Professional Publishing.

Vincent, J. F. R. (2000, August). Genuine savings in Latin America: Estimates for 1973-97. Center for International Development, Harvard University. 2000. Retrieved from www.cid.harvard. edu

World Commission. (1987). Our common future (Brundtland Report). Presentation of the Report of the World Commission on Environment and Development to UNEP's 14th Governing Council Session.

World Conservation Strategy. (1980). Living resource conservation for sustainable development. (IUCN/WWF/UNEP, 1980).

World Development Indicators. (WDI). Various years. World Bank Publications. 
IJMS 19 (1), 151-174 (2012)

\section{Appendix}

Table A1

Value of GS and GDP for Malaysia (in million USD)

\begin{tabular}{|c|c|c|}
\hline Year & Genuine Savings* & Gross Domestic Products \\
\hline 1990 & $6,285.31$ & $44,024.18$ \\
\hline 1991 & $7,363.41$ & $49,133.85$ \\
\hline 1992 & $11,995.41$ & $59,151.29$ \\
\hline 1993 & $16,186.37$ & $66,894.45$ \\
\hline 1994 & $19,154.75$ & $74,480.82$ \\
\hline 1995 & $23,347.92$ & $88,832.45$ \\
\hline 1996 & $29,021.23$ & $100,852.00$ \\
\hline 1997 & $29,633.42$ & $100,169.00$ \\
\hline 1998 & $24,920.58$ & $72,175.31$ \\
\hline 1999 & $27,023.67$ & $79,148.42$ \\
\hline 2000 & $25,676.77$ & $93,789.74$ \\
\hline 2001 & $23,645.33$ & $92,783.95$ \\
\hline 2002 & $26,862.15$ & $100,846.00$ \\
\hline 2003 & $28,336.70$ & $110,202.00$ \\
\hline 2004 & $30,933.84$ & $124,749.00$ \\
\hline 2005 & $29,204.47$ & $137,848.00$ \\
\hline 2006 & $33,155.42$ & $156,523.00$ \\
\hline 2007 & $39,742.87$ & $185,981.00$ \\
\hline 2008 & $42,233.58$ & $221,161.00$ \\
\hline
\end{tabular}

* Calculated by the authors 


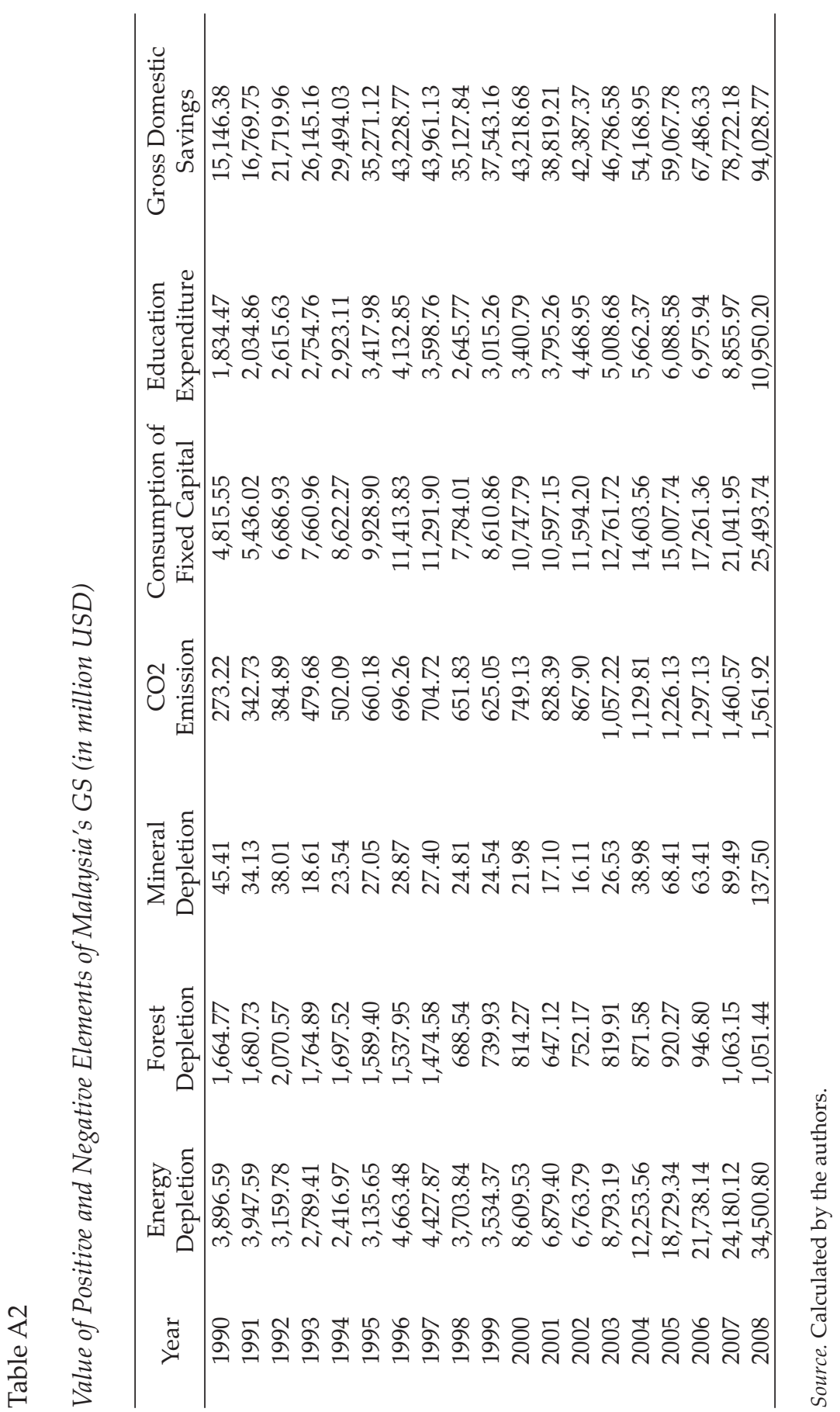


IJMS 19 (1), 151-174 (2012)

Table A3

Sources of Data for GDS, Consumption of Fixed Capital and Education Expenditure

\begin{tabular}{|c|c|c|c|}
\hline No. & Data & Sources & URL \\
\hline 1 & $\begin{array}{l}\text { Gross Domestic } \\
\text { Savings }\end{array}$ & $\begin{array}{l}\text { The Asian Development } \\
\text { Bank (Key Indicators for } \\
\text { Asia and the Pacific 2009: } \\
\text { Malaysia) }\end{array}$ & $\begin{array}{l}\text { http://www.adb.org/ } \\
\text { Documents/Books/Key_- } \\
\text { Indicators/2009/pdf/MAL. } \\
\text { pdf }\end{array}$ \\
\hline 2 & $\begin{array}{l}\text { Consumption of } \\
\text { Fixed Capital }\end{array}$ & $\begin{array}{l}\text { The World Bank } \\
\text { (Indicator for Malaysia) }\end{array}$ & $\begin{array}{l}\text { http://data.worldbank. } \\
\text { org/country/malaysia }\end{array}$ \\
\hline 3 & $\begin{array}{l}\text { Education } \\
\text { Expenditure }\end{array}$ & $\begin{array}{l}\text { - Mengurus dan } \\
\text { Membiayai Pendidikan } \\
\text { di Malaysia by Shahril } \\
\text { Marzuki (2005) } \\
\text { - Economic Report of } \\
\text { Malaysia, various years }\end{array}$ & $\begin{array}{l}\text { http://www.treasury. } \\
\text { gov.my/index }\end{array}$ \\
\hline
\end{tabular}

Table A4

Sources Data for Production of Natural Resources and $\mathrm{CO}_{2}$

\begin{tabular}{|c|c|c|c|}
\hline \multicolumn{2}{|c|}{ No. Data } & Sources & URL \\
\hline 1 & $\begin{array}{l}\text { Mineral } \\
\text { - Bauxite }\end{array}$ & U.S. Geological Survey & $\begin{array}{l}\text { http://minerals.usgs.gov/minerals/ } \\
\text { pubs/country/ }\end{array}$ \\
\hline & - Tin & U.S. Geological Survey & $\begin{array}{l}\text { http://minerals.usgs.gov/minerals/ } \\
\text { pubs/country/ }\end{array}$ \\
\hline & - Gold & U.S. Geological Survey & $\begin{array}{l}\text { http://minerals.usgs.gov/minerals/ } \\
\text { pubs/country/ }\end{array}$ \\
\hline & - Iron Ore & U.S. Geological Survey & $\begin{array}{l}\text { http://minerals.usgs.gov/minerals/ } \\
\text { pubs/country/ }\end{array}$ \\
\hline 2 & $\begin{array}{l}\text { Energy } \\
\text { - Petroleum }\end{array}$ & U.S. Geological Survey & $\begin{array}{l}\text { http://minerals.usgs.gov/minerals/ } \\
\text { pubs/country/ }\end{array}$ \\
\hline & - Gas & U.S. Geological Survey & $\begin{array}{l}\text { http://minerals.usgs.gov/minerals/ } \\
\text { pubs/country/ }\end{array}$ \\
\hline & - Coal & U.S. Geological Survey & $\begin{array}{l}\text { http://minerals.usgs.gov/minerals/ } \\
\text { pubs/country/ }\end{array}$ \\
\hline 3 & Timber & $\begin{array}{l}\text { Department of Statistics } \\
\text { Malaysia. Statistic Year Book } \\
\text { of Malaysia (Production of } \\
\text { Logs Malaysia) }\end{array}$ & \\
\hline 4 & $\mathrm{CO}_{2}$ & $\begin{array}{l}\text { The World Bank (Indicator } \\
\text { for Malaysia) }\end{array}$ & $\begin{array}{l}\text { http://data.worldbank.org/country/ } \\
\text { malaysia }\end{array}$ \\
\hline
\end{tabular}


IJMS 19 (1), 151-174 (2012)

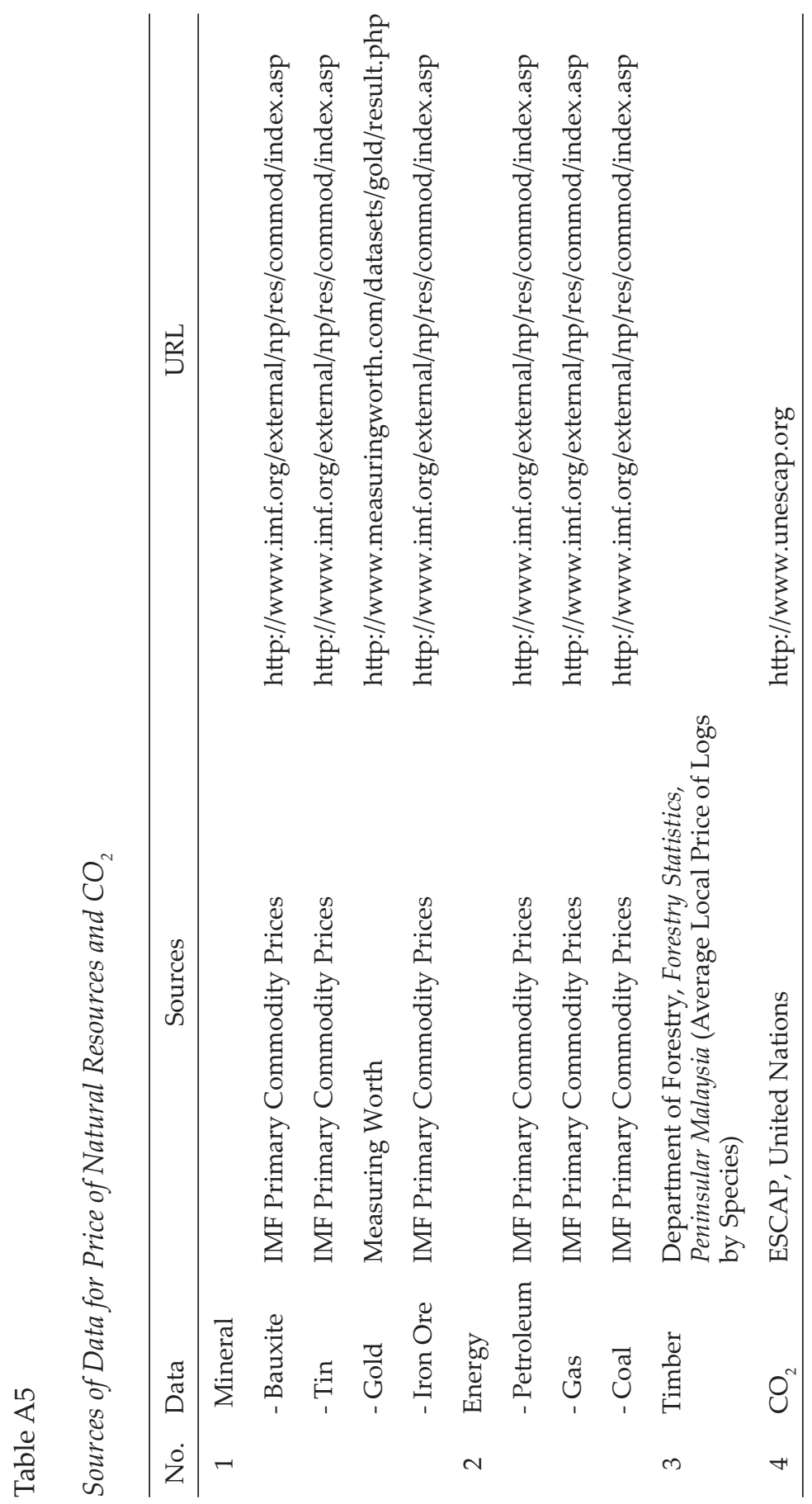


IJMS 19 (1), 151-174 (2012)

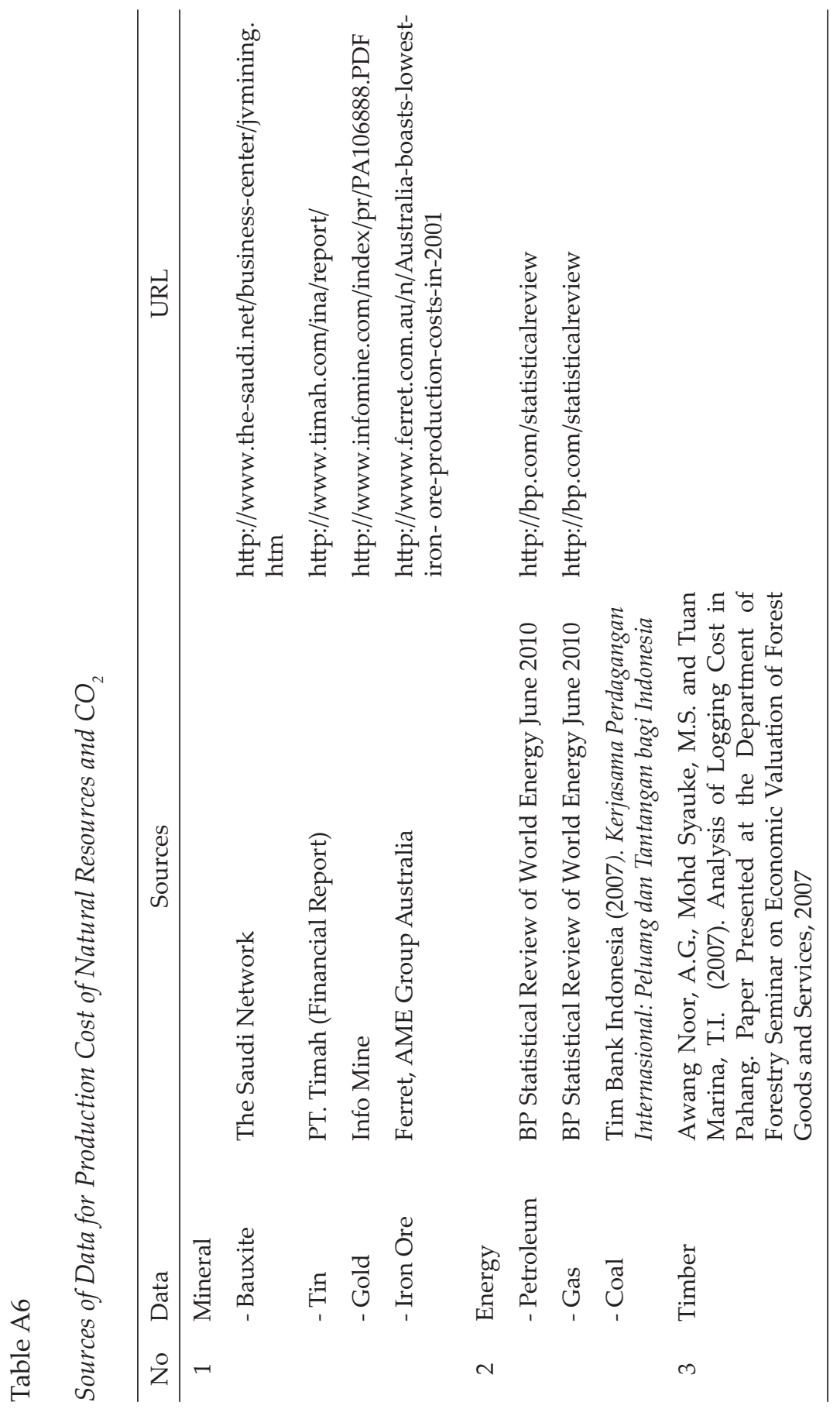

